Portland State University

PDXScholar

\title{
The Elementary and Secondary Education Act
} (ESEA) and its Reauthorization as the Improving America's Schools Act (IASA) with its Impact on Funding, Education Policy, and Supporting the Change for Improvement of Student Achievement

Kaylee LaTocha

Portland State University

Follow this and additional works at: https://pdxscholar.library.pdx.edu/honorstheses

Part of the Educational Assessment, Evaluation, and Research Commons, Education Law Commons, Elementary Education Commons, Other Education Commons, and the Secondary Education Commons Let us know how access to this document benefits you.

\section{Recommended Citation}

LaTocha, Kaylee, "The Elementary and Secondary Education Act (ESEA) and its Reauthorization as the Improving America's Schools Act (IASA) with its Impact on Funding, Education Policy, and Supporting the Change for Improvement of Student Achievement" (2021). University Honors Theses. Paper 1032.

https://doi.org/10.15760/honors.1058

This Thesis is brought to you for free and open access. It has been accepted for inclusion in University Honors Theses by an authorized administrator of PDXScholar. Please contact us if we can make this document more accessible: pdxscholar@pdx.edu. 
The Elementary and Secondary Education Act (ESEA) and its Reauthorization as the Improving America's Schools Act (IASA) with its impact on funding, education policy, and supporting the change for improvement of student achievement

By

Kaylee LaTocha

An undergraduate honors thesis submitted in partial fulfillment of the

Requirements for the degree of
Bachelor of Science
In
University Honors
And
History

Thesis Adviser

Katrine Barber

Portland State University 


\section{Acknowledgments}

The two that helped me through the writing process were my advisor Katrine Barber, who was there since I first asked her to be my advisor, and my good friend Daniel Fujimoto who was my editor in the final months of writing. They had managed to push me through the doubt and work towards the final thesis which I couldn't be more grateful for. And a thank you to my family and friends who had cheered me on to see me graduate. My parents, Kelli LaTocha, Darius LaTocha, and Michelle La Tocha who all pushed to see me in college, to my grandparents who offered support, to my friends Bella Papakristo, Sophie Cin, and Tia Kelliher who were there for me when I needed them. To all the rest that I love and have been there for me when I needed them.

Thank you 


\section{Introduction:}

Education is at the core of what molds a child's future. Education is also the core of this conversation. The core, or in this analogy fitting of America -- a football game, is represented by the football, and the players take the field. Who are these players? Among them are the presidents, the head of departments, senators, organization leaders, administrators and the like, dashing, running, or protecting their own. The football will get passed back and forth as opposing sides think they have the winning idea - they have the solution. However, where are the students? One must assume that the students the legislation was meant to help would also get a turn to hold the ball. The crowd looks to see where they are, only to find them alone on the bench, watching from the sidelines. They are no more than spectators themselves as they watch their future in the hands of others that say what they think is best. This thesis will address the Elementary and Secondary Education Act of president Johnson's administration and the Improving America's Schools Act of the Clinton administration. The essay will not fully cover the reauthorizations in between the acts or any reauthorization after. I will be focusing my attention on K-12 public schools and not on higher education or nonpublic schools.

Within the first decade of the 20th century, the nation's educators realized that it was necessary to create educational organizations to establish the education industry as a profession. Organizations provided a sense of unity to a group that before had no collective authority and agreed-upon standards within the United States' state-based education system. Teachers and administrators began to form their own organizations, so members could participate collectively on a political level as at this time, there was only an Office of Education that was much smaller in size and effectiveness than today's Department of Education. Organizations, such as the American Federation of Teachers (AFT, founded 1916) and the National Education Association 
(NEA, founded 1857), held committees and conventions where they attempted to operate as a system to unify districts and give them a voice in the government as a part of the U.S. educational system. ${ }^{1}$ Outside these organizations, there was little consolidation of standards between the states. States all had their own standards that did not adhere to an overall agenda, and they had no platform for communication. These national organizations however, provided a means of conducting and sharing research, funded by money collected from their membership, and created a foundation of expectations for themselves, one of the few places where connections between states were taking place. ${ }^{2}$ These types of organizations took on a larger role in driving educational decision-making in the latter half of the 20th century.

These educational organizations wanted their association to be national organizations that connected each state through unity and the communication of educational efforts between schools and districts. They wanted to give teachers, principals, and administrators a level of professionalism through the program. Similar standards of professionalism in other fields included the same benefits associated with other professions such as salary, security, and retirement. ${ }^{3}$ They had the means of acquiring these benefits once union activity increased in the 1960s. ${ }^{4}$ The NEA, having a larger contribution to national education policy later on, felt that their role was to fill in for the absence of the government, thus most organizations were not governmental in origin, but took the responsibility in working with the government to ensure

\footnotetext{
${ }^{1}$ Lyle W. Ashby, "The National Education Association," The Phi Delta Kappan 31, no. 3 (1949): 101, Accessed December 3, 2020, http://www.jstor.org/stable/20331887.

${ }^{2}$ Denise Cardinal, "National Education Association," in Encyclopedia of Education, 2nd ed., ed. James W. Guthrie (New York, NY: Macmillan Reference USA, 2002), 1769, Vol. 5, Gale eBooks, accessed October 31, 2020, https://link.gale.com/apps/doc/CX3403200451/GVRL?u=oregon portland\&sid=GVRL\&xid=9e710060.

${ }^{3}$ Lyle W. Ashby, "The National Education Association," The Phi Delta Kappan 31, no. 3 (1949): 102, Accessed December 3, 2020, http://www.jstor.org/stable/20331887.

${ }^{4}$ Caroline Minter Hoxby, "How teachers' unions affect education production," Quarterly Journal of Economics 111 , no. 3 (1996): 675, Gale OneFile: Business, Accessed November 18, 2020, https://link.gale.com/apps/doc/A18673683/GPS?u=s1185784\&sid=GPS\&xid=3274fc4c.
} 
education in the U.S. was being paid attention to, while also getting policies created for the needs of those working in the education industry or pursuing an education. ${ }^{5}$ After the creation of unions for educators, these organizations pushed for lobbying and for more involvement in politics.

The federal role in education changed significantly in the mid-twentieth century. The beginning of the Cold War was a push for the federal government to identify economic equity amongst students attending school as a need. As a result, the Elementary and Secondary Education Act (ESEA), which was supposed to change these inequities by closing the wealth gap, was signed by President Lyndon Johnson in 1965. This act provided funding for schools and support for education programs. The original act had six titles with the seventh added in 1967. The realization that a higher-skilled workforce was needed provided the rationale for managing standards at the federal level. The ESEA provided resources in support of students to achieve state standards while each state had to track their own progress. Before this, states did not keep much data as it was not required federally. In the 1990s, the federal government tracked statistics and followed up with their progress more regularly.

Another turning point in federal education policy occurred in 1979, when the Department of Education, which combined several agencies under an umbrella, was established under president Jimmy Carter. Carter had promised the NEA to establish the agency, in exchange for supporting his campaign to become the next president. ${ }^{6}$ Between the passage of the ESEA in 1965 and the passage of the IASA in 1994, federal administrations reauthorized the ESEA, making adjustments, such as increasing the budget and adding amendments. Resistance to the policy occurred when conservative presidents, preferring to decrease the budget, stipulated that

\footnotetext{
${ }^{5}$ The SAGE Encyclopedia of Educational Research, Measurement, and Evaluation, Achievement Tests, by Yi-Fang Wu ed. Bruce B. Frey (Thousand Oaks: SAGE Publications, Inc., 2018), http://dx.doi.org/10.4135/9781506326139, Accessed April 13, 2021.

${ }^{6}$ David Stephens, "President Carter, the Congress, and NEA: Creating the Department of Education." Political Science Quarterly 98, no. 4 (1983): 463, Accessed January 26, 2021, doi:10.2307/2149722.
} 
evidence did not show that providing more money would benefit students. ${ }^{7}$ They also pushed to remove decisions from federal hands in favor of state and local leadership. Congress and the NEA were very vocal in disapproving budgetary cuts and policy revisions, resulting in many vetoes and revisions of the educational policy.

During the Clinton administration, the Improving America's Schools Act was created as one of the reauthorizations of the ESEA. The reinstatement of the IASA, the revised ESEA, gave more power to states and districts by setting up end goals, but leaving how they meet these goals up to the states. The act implemented professional development for teachers and other school staff, provided flexibility for how schools implemented the various federal programs from IASA, held schools accountable for improving student achievement, and promoted partnerships between schools with families and communities. ${ }^{8}$ Accountability of schools at a state and local level determined distribution of funding.

These two pieces of legislation, the ESEA signed by President Lyndon Johnson and its reauthorization, the IASA signed by President Bill Clinton, directly shaped education in the U.S. Both acts consolidated funding even if the main function of each had different purposes. Both the ESEA and the IASA were responses to large changes in the nation in addressing how to improve upon the state of education. As standards of education and student achievement evolved, politicians were aware that there were problems in funding what had already been established. They were also intent on measuring the success of educational policy through the collection and analysis of data collected across the nation.

\footnotetext{
${ }^{7}$ Lawrence J. McAndrews, The Era of Education: The Presidents and the Schools, 1965-2001 (Champaign: University of Illinois Press, 2006.), 34, ProQuest Ebook Central.

${ }^{8}$ McAndrews, The Era of Education: The Presidents and the Schools, 1965-2001, 157.
} 


\section{History and context:}

Since the founding of the US, the federal role in education had been negligible up until recently. Politicians had previously brought up ideas of what should be done for education at a national level, but they were rejected by others. The question of having federal aid had the public and the politicians fearing that it could potentially open the door to the federal government having more control. ${ }^{9}$ Education up until the 1930 s was mostly a state function and the federal government was second. A fear of federal control felt all too real during the Red Scare. Even before, however, there was little interest in having the country intervene in education at the federal level. It only came about as one of the New Deal's financial reforms to help fuel the economy. Such aid, like grants and scholarships were given to help citizens attend school while other money was given to projects to increase employment. ${ }^{10}$ Of course, the government was not the only ones who had a say on if the government should provide federal aid. Educational organizations such as the NEA, the National Catholic Welfare Conference (NCWC), and the AFT thought there should be federal aid given to schools, however they were all apprehensive about this leading to further federal interference. ${ }^{11}$ The NCWC raised concerns because at this time religion and education was further separating and they voiced that nonpublic schools needed funding the same as public ones. ${ }^{12}$ The AFT and the NEA now having a large membership in different states, had made themselves a political player to be reckoned with. We see this play out in the later half of the 20th century. Politicians and legislation were now forced

\footnotetext{
${ }^{9}$ David Casalaspi. "The Making of a "Legislative Miracle": The Elementary and Secondary Education Act of 1965." History of Education Quarterly 57, no. 2 (May, 2017): 247-277, doi:http://dx.doi.org/10.1017/heq.2017.4. ${ }^{10}$ Congress of the U.S., Elementary and Secondary Education Act of 1965, Background Material With Related Presidential Recommendations, n.a., Washington D.C.:ERIC Clearinghouse, 1965, https://files.eric.ed.gov/fulltext/ED018492.pdf, Accessed January 16, 2021.

${ }^{11}$ Lawrence J. McAndrews, The Era of Education: The Presidents and the Schools, 1965-2001 (Champaign: University of Illinois Press, 2006.), 4, ProQuest Ebook Central.

${ }^{12}$ Julia Hana, "The Elementary and Secondary Education Act: 40 Years Later," Harvard Graduate School of Education, President and Fellows of Harvard College, last modified August 18, 2005, https:/www.gse.harvard.edu/news/05/08/elementary-and-secondary-education-act-40-years-later.
} 
to meet their approval, putting the education system at the mercy of another organized group's agenda, and not the will of the people.

Before the ESEA, there was a significant amount of focus on educational policy during the time of World War Two to educate the military. There was the Lanham Act 1941 which, "...funded school services and construction for soldiers and their children."13 A bill was passed in 1943 because there were numerous rejections in the military due to illiteracy. ${ }^{14}$ Education funding, at this time, was a temporary solution, passing bills that would provide aid for the problems at hand, and never for any long term solutions. Half of school districts had no kindergarten classes and even fewer had preschool programs. ${ }^{15}$ Most elementary schools had no libraries and had no librarians. The statistics of who attended and who graduated from schools were collected on a state by state basis. Eventually the Lanham Act of 1941 and the GI Bill were extended due to their proven success. ${ }^{16}$

$\underline{\text { Johnson and political issues (Presidents and their influence on education) - }}$

Like much of our legislation, the ideas of what education should and should not be were split between Democrats and Republicans. To understand what was going on at the time of Johnson's presidency, we have to look at him as an extension of Kennedy. In being his vice president they had similar attitudes about policy. However, Kennedy was not as left leaning as Johnson. This is typically attributed to his upbringing in a wealthy family. Much of the academic rhetoric when looking at federal education policy revolves around the president's own experience

\footnotetext{
${ }^{13}$ Lawrence J. McAndrews, The Era of Education: The Presidents and the Schools, 1965-2001 (Champaign: University of Illinois Press, 2006), 2, ProQuest Ebook Central.

${ }^{14}$ Janice Sweet McElhoe, "Compensatory Education: A Comparison of the Design and Intent of Title I of the Elementary and Secondary Education Act: 1965 to 1994" (diss., The Pennsylvania State University, 1995 ), 27.

${ }^{15}$ Congress of the U.S., Elementary and Secondary Education Act of 1965, Background Material With Related Presidential Recommendations, n.a., Washington D.C.:ERIC Clearinghouse, 1965, https://files.eric.ed.gov/fulltext/ED018492.pdf, Accessed January 16, 2021.

${ }^{16}$ Lawrence J. McAndrews. Broken Ground: John F Kennedy and the Politics of Education (London: Taylor \& Francis Group, 2012), 12, ProQuest Ebook Central.
} 
in education as a driving factor in how they think educational policy should be. Having attended private schools, McAndrews describes that Kennedy was unable to make the connection between poverty and poor education whereas Johnson was able to due to his past of both attending and working in public schools in Texas. ${ }^{17}$

The main three issues that Kennedy as well as Johnson were facing are summed up with the three R's: Reds (federal control), race, and religion. ${ }^{18}$ The "Reds" and religion aspect were touched upon above, and race will soon come into play. There was also a different type of Red that was about to take center stage in U.S. politics. Two global events were taking place that directly impacted the Johnson administration, which also meant they affected the ESEA's creation. One was the Cold War. Historians place the Cold War Era beginning in 1945, immediately following the end of World War 2, and ending in $1991 .{ }^{19}$ This included the time of the Red Scare where the U.S. was combating communism in various countries. The fight between the Soviets and the Americans at this time was about who would come out on top: the Capitalist or the Communist? Which would overpower the other? During the Space Race with the Soviets, there was growing fear of their superior technology when, in 1957, they launched Sputnik into space. ${ }^{20}$ This was a time when both the government and U.S.citizens experienced tension as no one was sure what such unfamiliar technology would mean for the future.

Congress passed the National Defense Education Act allowing federal money to be used for loans in subjects such as STEM or in language programs that could be used against the

\footnotetext{
${ }^{17}$ McAndrews, Broken Ground: John F Kennedy and the Politics of Education, 7.

${ }^{18}$ James W. Guthrie, “A political case history: Passage of the ESEA,” Phi Delta Kappan, 49(6), (1968): 302-306, https://kappanonline.org/political-case-history-passage-esea-guthrie/.

19 “Timeline of the Cold War," Truman Library, Accessed May 5, 2020, https://www.trumanlibrary.gov/public/TrumanCIA_Timeline.pdf.

${ }^{20}$ U.S. Department of Health, Education \& Welfare, Office of Education, ELEMENTARY AND SECONDARY EDUCATION ACT OF 1965 Background Material With Related Presidential Recommendations, n.a., ERIC Clearinghouse, 1965, https://files.eric.ed.gov/fulltext/ED018492.pdf ,Accessed February 12, 2021.
} 
Soviets. ${ }^{21}$ This trend was further established when the government itself and their encouragement of corporations endorsed STEM subjects in the latter half of the twentieth century. ${ }^{22}$ As stated by McGuinn the NDEA from 1958, “... and the Elementary and Secondary Education Act of 1965, however, national policymakers have used the grant-in-aid system to pursue federal goals in public education." ${ }^{23}$ These goals were immediate. In the case of the NDEA, it was from the fear of communism outperforming the U.S., and as will be discussed later, the ESEA was more than a way to consolidate funding. All these trends show that in the first half of the twentieth century, the only time that education was seen as a concern was when it affected the country's bottom line. As I see it, America's ideals on capitalism were absolute, and the U.S. protected their ideals as a superpower who was combatting the Reds. This is the narrative that is being presented.

As the government was worried about this outer threat, the internal threat that worried citizens at the time was racism. The Civil Rights movement was in full swing during the 1950s and while there were attempts to correct overt racism, but not much to help the systemic racism that had seemed to go unnoticed. In President Eisenhower's time, there were federal aid bills proposed as well as an anti-segregation amendment known as the Powell amendment. ${ }^{24}$ The focus of the people was primarily on the anti-segregation amendments, and the entirety of the civil rights movement as a whole. Those campaigning for equal rights and long term solutions to fundamental issues in the countries' government had the focus of the entire country, leaving the educational reforms forgotten at this time. Johnson signed the Civil Rights Act in 1964 which

\footnotetext{
${ }^{21}$ Lawrence J. McAndrews, Broken Ground: John F Kennedy and the Politics of Education (London: Taylor \& Francis Group, 2012), 2, ProQuest Ebook Central.

${ }^{22}$ Lawrence J. McAndrews, The Era of Education: The Presidents and the Schools, 1965-2001 (Champaign: University of Illinois Press, 2006), 140, ProQuest Ebook Central.

${ }^{23}$ Patrick McGuinn, "Schooling the State: ESEA and the Evolution of the U.S. Department of Education" RSF: The Russell Sage Foundation Journal of the Social Sciences 1, no. 3 (2015): 77, Accessed April 7, 2021, doi:10.7758/rsf.2015.1.3.04.

${ }^{24}$ Lawrence J.McAndrews, Broken Ground: John F Kennedy and the Politics of Education (London: Taylor \& Francis Group, 2012), 44, ProQuest Ebook Central.
} 
coincided with the War on Poverty due to the fact that he acknowledged the tie between poverty and racial injustice.There was an awareness of the education inequality between blacks and whites which may have impacted Johnson's stance on education equality. ${ }^{25}$ Johnson argued that it was to face the nation's poverty issue that he wanted to close the gap between rich and poor students. Much of his plans involved increasing help to social welfare programs and inviting more people willing to be active in voting and in politics. Orleck and Hazirjian said that Johnson saw the U.S. in need and that," To produce a 'Great Society' that 'rests on abundance and liberty for all,' the Johnson administration launched programs to provide education, job training, employment, medical care, and housing." ${ }^{26}$ Johnson signed off on The Economic Opportunity Act also in 1964. This provided Youth Opportunity Centers and the inclusion of libraries as a public place for learning. ${ }^{27}$ At the time, there was a strong push for libraries to be used and essential as a learning space and gathering area of knowledge for everyone. A place where there were endless books to read was important because Johnson wanted to raise national literacy, which was defined as having the ability to read at the fifth grade level. ${ }^{28}$

\section{Elementary and Secondary Education Act (ESEA):}

The United States saw large expansions of school enrollment no doubt spurred on by the second industrial revolution around the early 1900s which may have left the government ill prepared to handle. ${ }^{29}$ Student evaluation before the 1960 's was disorganized, "During the

\footnotetext{
${ }^{25}$ Lawrence J. McAndrews, The Era of Education: The Presidents and the Schools, 1965-2001 (Champaign: University of Illinois Press, 2006), 11, ProQuest Ebook Central.

${ }^{26}$ Annelise Orleck, and Lisa Gayle Hazirjian, War on Poverty: A New Grassroots History, 1964-1980 (Athens: University of Georgia Press, 2011), 63, Accessed January 26, 2021, ProQuest Ebook Central.

${ }^{27}$ U.S. Department of Health, Education \& Welfare, Office of Education, War On Poverty, by Henry T. Drenman. ERIC Clearinghouse, 1964, https://files.eric.ed.gov/fulltext/ED021882.pdf, Accessed February 13, 2021.

${ }^{28}$ U.S. Department of Health, Education \& Welfare, Office of Education, War On Poverty.

${ }^{29}$ Ohio State Legislative Office of Education Oversight, Columbus, Measuring Student Achievement, n.a., Ohio ERIC Clearinghouse, 1993, https://files.eric.ed.gov/fulltext/ED411290.pdf, Accessed March 7, 2021.
} 
'twenties evaluation had little relation to the curriculum, standardized tests were constructed to conform with a given textbook or with the author's idea of what the objective of the area being measured. ${ }^{{ }^{30}}$ Education needed to be measured through a quantitative standard. ${ }^{31}$ The first use of standardized tests and IQ tests was turned into a pre-screening test for immigrants on Ellis Island within "quantifiable terms" to see if the people were "fit" to be allowed into America. ${ }^{32}$ The introduction of testing in an academic setting as a form of measurement was in 1925, “...the College Board requested an intelligence test for college admission to be prepared to test the aptitude of junior and senior high school students for college-level work. Thus, the SAT was introduced." ${ }^{33}$ Testing on kids began because of psychologist's interest in the relationship between how much time was spent on subjects and student achievement in these subject areas. ${ }^{34}$ Herein lies a major part of the modern education system that persists. Later on when screening was needed for the war, similar tests were implemented on recruits to get into the army. The government realized that their citizens were unable to pass such tests and that is how the GI Bill and other similar legislation came to be.

President Lyndon Johnson was concerned with addressing the needs of the growing population, "Congress had passed several programs which provided limited and specific aid to elementary and secondary education between 1940-1965, but was less successful with general aid. ${ }^{\text {35 }}$ Johnsons emphasized the War on Poverty because he was aware of the direct relationship between poverty and deficient education. A solution to negate poverty was to provide more

\footnotetext{
${ }^{30}$ Hugh B. Wood, Evaluation of Pupil Growth and Development; A Study-Guide for Students and Teachers (Urbana-Champaign: University of Illinois, 1940), 19, HathiTrust.

${ }^{31}$ Wood, Evaluation of Pupil Growth and Development; A Study-Guide for Students and Teachers, 23.

${ }^{32}$ Ibid 15,; Ohio State Legislative Office of Education Oversight, Columbus, Measuring Student Achievement, n.a., Ohio: ERIC Clearinghouse, 1993, https://files.eric.ed.gov/fulltext/ED411290.pdf, Accessed March 7, 2021.

${ }^{33}$ Ohio State Legislative Office of Education Oversight, Columbus, Measuring Student Achievement.

${ }^{34}$ Ibid, 5.

${ }^{35}$ Janice Sweet McElhoe, "Compensatory Education: A Comparison of the Design and Intent of Title I of the Elementary and Secondary Education Act: 1965 to 1994" (PhD diss., The Pennsylvania State University, 1995), 27.
} 
funding. There were many kids dropping out before finishing high school and those that graduated high school did not go on to college. Jobs filled by students who had higher education went up where those only receiving an 8 th grade education had higher rates of unemployment. ${ }^{36}$ Passing the ESEA -

Lyndon Johnson pushed education believing it was the people's number one priority. $\mathrm{He}$ argued that it was to face the nation's poverty issue. He was right in the middle of the Space Race where technology and communication advancement was growing, and these newer industries would need jobs that required a higher level of education. ${ }^{37}$ Johnson was also concerned with the needs of a growing population as that meant he needed more classrooms and staff to lead the classes. ${ }^{38}$ Many students dropped out before finishing high school and those that graduated did not go onto college which Johnson spoke of, calling out the nation for such neglect. ${ }^{39}$ Johnson, during his electoral win, had a majority in both houses of Congress which meant that any opposition was unable to block the bill. His goal was to improve education for the individual, which in turn helped the nation, as the people were an investment to the nation's future. ${ }^{40}$

His first priority was to low-income school districts, giving them school library resources and instructional materials, supplementary educational centers and services, and regional education labs for developing new training and curriculums. ${ }^{41}$ They made it so that schools that

\footnotetext{
${ }^{36}$ McElhoe, "Compensatory Education: A Comparison of the Design and Intent of Title I of the Elementary and Secondary Education Act: 1965 to 1994"), 28.

${ }^{37}$ Congress of the U.S., Elementary and Secondary Education Act of 1965, Background Material With Related Presidential Recommendations, n.a., Washington D.C.:ERIC Clearinghouse, 1965, https://files.eric.ed.gov/fulltext/ED018492.pdf, Accessed January 16, 2021.

${ }^{38}$ Congress of the U.S., Elementary and Secondary Education Act of 1965, Background Material With Related Presidential Recommendations.

39 Janice Sweet McElhoe, "Compensatory Education: A Comparison of the Design and Intent of Title I of the Elementary and Secondary Education Act: 1965 to 1994" (PhD diss., The Pennsylvania State University, 1995), 28.

${ }^{40}$ McElhoe, "Compensatory Education: A Comparison of the Design and Intent of Title I of the Elementary and Secondary Education Act: 1965 to 1994", 29.

${ }^{41}$ Congress of the U.S., Elementary and Secondary Education Act of 1965, Background Material With Related Presidential Recommendations, n.a., Washington D.C.:ERIC Clearinghouse, 1965, https://files.eric.ed.gov/fulltext/ED018492.pdf, Accessed January 16, 2021.
} 
received funding under Title 1 had to follow desegregation guidelines to qualify. ${ }^{42} \mathrm{He}$ wanted to strengthen state education agencies and focus on higher education to follow the trend of what jobs were hiring. Students needed monetary assistance, and educational options they could afford, like scholarships, aid to smaller colleges, and more support for college library resources. ${ }^{43}$ The bill was not for the federal government to assume control of education, but rather Johnson said it should be their obligation to fund it. ${ }^{44}$ The library was seen as an effective tool that included the librarians to help as a guide to help people learn. ${ }^{45}$

ESEA supposed to do -

When Johnson signed off on the Elementary and Secondary Education Act, he saw it as a means of addressing poverty as well as other social issues of the time. To break down the act itself, it was divided into 6 Titles: Title 1 had funds distributed by state officials to help local school districts. They could not fund construction projects or teacher salaries, but funding was shared with nonpublic schools. All students received equitable and high quality education and received most of the funds. Information would flow from local education agencies to state education agencies that would review their plans to make sure they were complying with the law. Title 2 provided money for textbooks and materials for public and nonpublic schools. Title 3 was for supplemental services and educational centers. Title 4 was to grant money for federal education research. Title 5 was to improve state education agencies. Lastly, Title 6 was simply to

\footnotetext{
${ }^{42}$ Julia Hana, "The Elementary and Secondary Education Act: 40 Years Later," Harvard Graduate School of Education, President and Fellows of Harvard College, last modified August 18, 2005, https://www.gse.harvard.edu/news/05/08/elementary-and-secondary-education-act-40-years-later.

${ }^{43}$ Congress of the U.S., Elementary and Secondary Education Act of 1965, Background Material With Related Presidential Recommendations, n.a., Washington D.C.:ERIC Clearinghouse, 1965, https://files.eric.ed.gov/fulltext/ED018492.pdf, Accessed January 16, 2021.

${ }^{44}$ Congress of the U.S., Elementary and Secondary Education Act of 1965, Background Material With Related Presidential Recommendation.

${ }^{45}$ U.S. Department of Health, Education \& Welfare, Office of Education, War On Poverty by Henry T. Drenman, ERIC Clearinghouse, 1964, https://files.eric.ed.gov/fulltext/ED021882.pdf Accessed February 13, 2021.
} 
provide general provisions to address anything that would have not been included in the previous titles. $^{46}$

In 1967, they added amendments to the act and federal aid increased. Each of these acts had a limit to where a certain percent must be utilized by each title. In order to receive funding, the states had to comply with guidelines laid out by Title $1 .{ }^{47}$ Reports were then given to the Department of Health, Education, and Welfare and the Office of Education. Unfortunately, little direction was given to the states or local agencies for implementing an education program for educationally deprived children because the federal government felt that it be left up to the states or agencies. ${ }^{48}$ There was a specific focus on groups who are at a disadvantage such as women, Indian, Native Hawaiian, and Alaska Education in the legislation. ${ }^{49}$ With the introduction of funds, the government created the question of how they were to decide what schools received funding and how much. Education specialists testified about possible techniques that would be more advantageous for students. ${ }^{50}$ One such technique used in the 1960s and 1970 s were, “.... the use of standardized achievement tests to meet ESEA assessment requirements developed incrementally. ${ }^{" 51}$ In this time, state and even federal criteria rose for measuring educational

\footnotetext{
${ }^{46}$ Department of Education, The Improving America's Schools Act of 1994. Reauthorization of the Elementary and Secondary Education Act, Washington D.C.: ERIC Clearinghouse, 1995, https://files.eric.ed.gov/fulltext/ED399649.pdf, Accessed January 19, 2021.

${ }^{47}$ Department of Education, The Improving America's Schools Act of 1994. Reauthorization of the Elementary and Secondary Education Act.

48 Janice Sweet McElhoe, "Compensatory Education: A Comparison of the Design and Intent of Title I of the Elementary and Secondary Education Act: 1965 to 1994" (PhD diss., The Pennsylvania State University, 1995), 17.

${ }^{49}$ U.S. Department of Health, Education \& Welfare, Office of Education, ELEMENTARY AND SECONDARY EDUCATION ACT OF 1965 Background Material With Related Presidential Recommendations, n.a., ERIC Clearinghouse, 1965, https://files.eric.ed.gov/fulltext/ED018492.pdf, Accessed February 12, 2021.

${ }^{50}$ Janice Sweet McElhoe, "Compensatory Education: A Comparison of the Design and Intent of Title I of the Elementary and Secondary Education Act: 1965 to 1994" (PhD diss., The Pennsylvania State University, 1995), 22.

${ }^{51}$ Office of Education DHEW, Washington, D.C. Div. of Compensatory Education, Staffing for Better Schools (Under Title I, Elementary and Secondary Education Act of 1965.) by Malcom Provus and Others, OE - 23049, Washington D.C.: ERIC Clearinghouse, 1967, https://files.eric.ed.gov/fulltext/ED034717.pdf, Accessed October 16, 2020 .
} 
success and the collection of data related to educational success. Education from this point on had shifted its efforts to focus on testing.

The ESEA was already an expensive bill on its own, now having to support the entire nation. Johnson had a plan to reduce funding while also taking off extra work for teachers. In how the ESEA was written, "Title 1 requires us to create more jobs serving children - but without requiring more teachers." ${ }^{, 52}$ They had training for aides to take on these tasks that did not require higher education. The government created volunteer programs with clubs as a way for the community to get involved and there were provisions of community resources. ${ }^{53}$ Tutors, another utilized resource, had their own curriculum for both in and out of school subjects. ${ }^{54} \mathrm{~A}$ more modern approach was becoming normalized at this time. Rather than have one teacher teaching several subjects, they preferred to have subject specialists in junior high and high schools that would only teach one subject. ${ }^{55}$ Another way of providing assistance were teacher seminars that were held for mutual support. Districts provided schools with guest speakers to bring in for student engagement. ${ }^{56}$ The hope was then that the teacher would have time to focus on the job. The tasks of a teacher were now reduced so that their time was not taken up with trivial tasks that could be done by others with less education.

\section{$\underline{\text { After the ESEA }}$}

Johnson acted like the ESEA was of the utmost importance, as that was where a lot of his legislation had its attention. However, it was pushed off to the margins and talked about less and less in Congress. ${ }^{57}$ Instead, the fight between Communism and Capitalism was the main issue as

\footnotetext{
${ }^{52}$ Office of Education DHEW, Washington, D.C. Div. of Compensatory Education, Staffing for Better Schools (Under Title I, Elementary and Secondary Education Act of 1965.).

${ }^{53}$ Ibid, 30.

54 Ibid, 24.

${ }^{55}$ Ibid, 12.

56 Ibid, 31.

${ }^{57}$ David Torstensson, “Beyond the City: Lyndon Johnson's War on Poverty in Rural America.” Journal of Policy History 25, no. 4 (2013): 587-613. doi:10.1017/S0898030613000316.
} 
the situation in Vietnam progressed further. Johnson, in trying to make peace, still did not want to show that the U.S. was willing to back down, "... the decision to continue the Vietnam commitment followed the path of his predecessors." ${ }^{58}$ Even if the U.S. lost the Vietnam War, they were essentially considered the victors of the Cold War. They were considered the superpower because of their constant intervention in other countries, and they won the space race by being the first to land on the moon.The U.S. did not give up the fight, “... it was viewed by the United States as part of the conspiracy by the Sino-Soviet bloc to conquer the Third World and install Communist regimes." ${ }^{59}$ But because of Johnson's continuation with the war he lost his Congressional majority in midterm elections and he could not get domestic measures through Congress.$^{60} \mathrm{He}$ had lost his ability to add more welfare type programs throughout the rest of his presidency as he was less trusted.

\section{History and context:}

After Johnson decided not to run for a second term in 1968, Nixon was elected president. He was not just having to be concerned about education. The Vietnam War was still ongoing and the containment of Communism was still a threat in southeast Asia. These outside impacts caused ripples through the U.S. affecting issues in education as the Commissioner of Education was dismissed for protesting the bombing of Cambodia that Nixon had agreed to. ${ }^{61}$ Indirectly, the war played a part in the economy performing poorly causing inflation and an increase in unemployment. $^{62}$

\footnotetext{
${ }^{58}$ Kent Germany, "Lyndon B. Johnson: Foreign Affairs," UVA Miller Center, Rector and Visitors of the University of Virginia, 2021, https://millercenter.org/president/lbjohnson/foreign-affairs.

${ }^{59}$ Germany, "Lyndon B. Johnson: Foreign Affairs."

${ }^{60} \mathrm{Ibid}$.

${ }^{61}$ Lawrence J. McAndrews, The Era of Education: The Presidents and the Schools, 1965-2001 (Champaign: University of Illinois Press, 2006), 21, ProQuest Ebook Central.

${ }^{62}$ McAndrews, The Era of Education: The Presidents and the Schools, 1965-2001, 23.
} 
I call attention to the fact that Nixon was a Republican as this is important to his stance on education. He was described as a man that played both sides, a trend that will become more popular where politicians say they are for one party, but may turn around to do something else not in alignment with their party's wants. Nixon's main goal was the standard for Republican attitudes toward education: a decreased budget. He was under the impression that education should be a selective system and that not all programs needed an increased budget. ${ }^{63}$ During his presidency, they found that Title 1 funds were not reaching disadvantaged children and because of this, Nixon wanted a cost-benefit analysis of the program. There was a present gap in urban students not being able to read. He created the Right to Read Program with the goal of getting 99\% of children reading. ${ }^{64}$ Due to his beliefs he had a negative relationship with the NEA and AFT, organizations that have remained left leaning. Beginning in the 70s, there was more political involvement from these nongovernmental affiliated organizations. He ended up increasing funds to end their disputes. It seems that his successor, President Ford was not able to create better relations with the NEA and the AFT even if the inflation issue was getting under control. ${ }^{65}$ Unfortunately, Congress was locked in battle constantly vetoing each other. Like the former president, Ford did not think that Title 1 was meeting its goal of equality. ${ }^{66}$ He thought that there should be federal funding towards research and development. Congress on the other hand was not as interested.

The establishment of the Department of Education in 1979 was because the NEA pushed for a larger federal role in elementary and secondary education. This would be the first time that education would stand as its own because before it was grouped with other industries such as

\footnotetext{
${ }^{63} \mathrm{Ibid}, 32$.

${ }^{64}$ Ibid, 20.

${ }^{65} \mathrm{Ibid}, 36$.

${ }^{66} \mathrm{Ibid}, 34$.
} 
Health or Agriculture. Originally, the NEA was non-partisan, but they created a Political Action Committee whose goal it is to raise money for political candidates. ${ }^{67}$ When running for president, Jimmy Carter said he promised the NEA that he would create the Department of Education, and they decided to endorse him, donating to his campaign ${ }^{68}$ When he won the election however, he seemed to be backtracking by not putting the Department as a priority. The NEA kept on pushing to make sure he stuck to his promise. Later on, Carter submitted a proposal to Congress to establish the role of the Department of Education, “...is to create policies that determine the allocation of federal funds for education. Conducting research about education in the U.S., detecting weakness in the education system and raise awareness, enforcing equal opportunity and not allowing discrimination in using educational programs and services.. ${ }^{99}$ The Department of Education was a win for the NEA, however, other politicians were frustrated at its creation.

The political sphere involved in education has now so many players that they have contributed to a more confusing system without even meaning to. There are clearly two distinct sides of education, but even within that, the groups are not willing to compromise. The presentation that there is a very strict divide in Republicans versus Democrats has been overly generalized as there are those that fall somewhere in between. The simplification itself is to demonstrate how the sides saw each other as opposing which led to their attitudes of not negotiating to find common ground. To recap all those that have authority in education, there is now the President, the Democratic politicians, the Republican politicians, the NEA, AFT, and a long list of other national education based organizations, while now adding the newly formed

\footnotetext{
67 "What Is a PAC?," OpenSecrets.org, The Center for Responsive Politics, Accessed April 28, 2021, https://www.opensecrets.org/political-action-committees-pacs/what-is-a-pac.

${ }^{68}$ David Stephens, "President Carter, the Congress, and NEA: Creating the Department of Education." Political Science Quarterly 98, no. 4 (1983): 463, Accessed January 26, 2021. doi:10.2307/2149722.

${ }^{69}$ The SAGE Encyclopedia of Educational Research, Measurement, and Evaluation, Achievement Tests, by Yi-Fang Wu ed. Bruce B. Frey (Thousand Oaks: SAGE Publications, Inc., 2018), http://dx.doi.org/10.4135/9781506326139, Accessed April 13, 2021.
} 
Department of Education to top it all off. All of them now had a hand in decision making as the NEA seemed to be pushing for a more centralized flow to education. During the $80 \mathrm{~s}$ and $90 \mathrm{~s}$, nongovernmental affiliated organizations such as AFT and NEA gained more influence in political decision making.

Clinton and political issues (Presidents and their influence on education)

Clinton was an influential politician in education even before becoming president and before the passing of the IASA. With the changes he made as governor in Arkansas, a lot of programs he wanted to include cost more than the budget allowed. ${ }^{70}$ Similarly, Clinton thought he could improve the ESEA by increasing the amount of money distributed, and get it to the students who needed it most. There were assumptions of the workforce's growth slowing in the 1990s. ${ }^{71}$ Clinton wanted to improve productivity and competitive position because he saw them as needs of the third industrial revolution. In 1990, they had the six educational goals established that the president wanted to be completed by the year $2000 .^{72}$ These goals were put into place by President Bush; any legislation that Clinton made had to make sure that they already followed within the trajectory these goals had established. There were assumptions that the workforce growth would slow in the 90 s, so the federal government wanted to improve productivity and competitive position. It was found to be a need of the third industrial revolution with the economic environment of having high skill jobs. An issue the U.S. had to deal with was a bad school to work transition. In 1990, a report from the National Center on Education and the

\footnotetext{
${ }^{70}$ Lawrence J. McAndrews, The Era of Education: The Presidents and the Schools, 1965-2001 (Champaign: University of Illinois Press, 2006), 131, ProQuest Ebook Central.

${ }^{71}$ Mid-Continent Regional Educational Lab., Aurora, CO., National Educational Goals: Can They Lead Schools to Real Reform? Noteworthy Series, n.a., Washington D.C.: ERIC Clearinghouse, 1990, https://files.eric.ed.gov/fulltext/ED369139.pdf, Accessed February 9, 2021.

${ }_{72}$ Mid-Continent Regional Educational Lab., Aurora, CO., National Educational Goals: Can They Lead Schools to Real Reform? Noteworthy Series.
} 
Economy found that the U.S. has a bad school to work transition and that $20 \%$ of students dropped out of high school. ${ }^{73}$

A memorable part of the Nixon administration was his declaration of the War on Drugs. Although he had officially declared his message to the U.S. in 1969, the horror of the Vietnam War, when it ended in 1975, added to this"public enemy." ${ }^{\prime 4}$ Veterans used heroin causing addictions ${ }^{75}$ Later on, President Reagan saw an increase in arrests on drug related charges, especially in minority communities. ${ }^{76}$ These are relevant to education as in the 1990 s there was an effort to make safe and drug free schools and communities. ${ }^{77}$ Clinton used his platform as a continuation of the previous president's stance on drugs having harsh sentences. ${ }^{78}$ His views carried over to how he handled parts of the IASA relating to the topic.

\section{Improving America's Schools Act (IASA):}

\section{Before the IASA -}

Since the beginning of his presidency, Ronald Reagan wanted to abolish the Department of Education and to reduce the budget. People thought that it should not exist without determining the role of what the federal government should be. Reagan wanted more state and local control of education and increased parental choice to invoke more competition between

\footnotetext{
${ }^{73}$ National Center on Education and the Economy, Rochester, NY., America's Choice: High Skills or Low Wages: The Report of the Commission on the Skills of the American Workforce, n.a. ISBN-0-9627063-0-2, New York: ERIC Clearinghouse, June 1990, https://files.eric.ed.gov/fulltext/ED323297.pdf, Accessed February 9, 2021.

74 “Timeline: America's War on Drugs,” NPR, NRP, April 2, 2007, https://www.npr.org/templates/story/story.php?storyId=9252490.

75 “Thirty Years of America's Drug War a Chronology," Frontline PBS, WGBH educational foundation, 2014, https://www.pbs.org/wgbh/pages/frontline/shows/drugs/cron/.

76 “A Brief History of the Drug War,” Drug Policy Alliance, Drug Policy Alliance, 2020, https://drugpolicy.org/issues/brief-history-drug-war.

${ }^{77}$ Library of Congress, Washington, D.C. Congressional Research Service, Improving America's Schools Act: An Overview of P.L. 103-382. CRS Report for Congress, by James B. Stedman, CRS- 94-872-EPW, Washington D.C: ERIC Clearinghouse, October 1994, https://files.eric.ed.gov/fulltext/ED379792.pdf Accessed April 5, 2021.

78 “A Brief History of the Drug War,” Drug Policy Alliance, Drug Policy Alliance, 2020, https://drugpolicy.org/issues/brief-history-drug-war.
} 
schools as well as include them in the education process. ${ }^{79}$ Conservatives wanted to minimize federal presence in education. As a method to do so, he attempted to outsource the offices to other departments as a way to dissolve its reason for existing. He wanted to transfer twenty-three programs to other departments. The Secretary of Education, Terrel Bell, found that there was opposition to this plan, so instead they opted to keep the department. Bell wanted to give out block grants to states by combining forty-four federal school aid programs which had the potential to eliminate Title $1 .{ }^{80}$ Carl Perkins, chairman of the House Committee on Education and Labor, however, tried to show that students served by Title 1 were at an advantage compared to students who did not receive their funding, "Instead of looking for ways to improve the education of children who are somehow disadvantaged, they tended to look for evidence to justify the continuation (or discontinuation!) of a federal funding program." ${ }^{, 81}$ With the continuing Cold War, there was a focus on math and science where companies that contributed to education in these fields were allowed tax deductions. Aptitude tests saw a decline in scores, many students had trouble with reading, math, and writing essays. ${ }^{82}$ The National Commission on Excellence in Education (NCEE), wanted to strengthen high school graduation requirements, raise standards for college admissions (restoring value of grades as indicators of value for academic achievement), and improve or dismiss teachers they thought unqualified. ${ }^{83}$ Bell gave commitment to literacy, basic math, and citizenship, values that still hold true in recent ESEA reauthorization as well as in the Department of Education. ${ }^{84}$ At this time, there was conflict

\footnotetext{
${ }^{79}$ National Center on Education and the Economy, Rochester, NY., America's Choice: High Skills or Low Wages: The Report of the Commission on the Skills of the American Workforce, n.a. ISBN-0-9627063-0-2, New York: ERIC Clearinghouse, June 1990, https://files.eric.ed.gov/fulltext/ED323297.pdf, Accessed February 9, 2021.

80 Lawrence J. McAndrews, The Era of Education: The Presidents and the Schools, 1965-2001 (Champaign: University of Illinois Press, 2006), 122, ProQuest Ebook Central.

${ }^{81}$ McAndrews, The Era of Education: The Presidents and the Schools, 1965-2001, 123.

${ }^{82} \mathrm{Ibid}, 124$.

${ }^{83} \mathrm{Ibid}, 129$.

${ }^{84}$ Lawrence J. McAndrews, The Era of Education: The Presidents and the Schools, 1965-2001 (Champaign: University of Illinois Press, 2006), 127, ProQuest Ebook Central.
} 
between the NEA and Reagan because his ideas were more right leaning. Disagreements left them at a stand still as the NEA pushed for more federal funding

Before enacting the Improving America's Schools Act, presidents still had an international focal point, yet internal players provided a pathway on the education front so that change would occur in education policy. Johnson had his attention on Vietnam, Nixon continued the war effort. Presidents are now being held accountable for following through with their promises in education policies by educational organizations and have played a large part in what has shaped education. Under Reagan a lot of the standards we still have in place today were created such as high school requirements of four years of math and language arts and three years of science and social studies.

With the new millennia around the corner, Bush thought that education could be improved through competitiveness. This is still what drives our modern standard of education. He placed an emphasis on what should be done with education in the future. Bush passed the Educational Excellence Act focusing on excellence, choice, accountability, and need and held an Education Summit in 1989 asking businesses to contribute, having the community take part in the education system. ${ }^{85}$ With his energy diverted to education, he was to be taken seriously as the education president which is what his administration wanted. The way he wanted to establish accountability in schools were annual report cards at every level to measure progress as a tool for money distribution. ${ }^{86} \mathrm{He}$ announced six education goals, which included increased literacy and graduation rates, school readiness of students before entering school and competency in specific subjects ${ }^{87}$ However some politicians, like Clinton, thought that, while potentially beneficial, one

\footnotetext{
${ }^{85}$ McAndrews, The Era of Education: The Presidents and the Schools, 1965-200, 122.

${ }^{86}$ Ibid, 136.

${ }^{87}$ Thomas Ferraro, "Bush announces six 'national education goals'," UPI, United Press International, Inc., February 1, 1990, https://www.upi.com/Archives/1990/02/01/Bush-announces-six-national-education-goals/2945633848400/.
} 
was unachievable due to unrealistic expectations of high achievement in math and in science within such a short time. The Department of Education was measuring spending per student would be best, including national exams at 4th, 8 th, and 12 th grade levels to measure progress of the state in the past year. ${ }^{88}$ His actions really sold to the public this image of education being a priority of the nation. Unfortunately, schools saw stagnation of performance. There was a realization that from the Johnson years they had refocused their efforts on the top two thirds economically instead of the bottom third as was intended. ${ }^{89}$ As a result, Bush increased Head Start funding, advocated for vouchers for low income students and gave money to the neediest districts. $^{90}$

Passing the IASA -

Revisions were made to the IASA to help meet the needs of students, integrate services, strategies, resources to reform the program, and help schools with the highest levels of poverty by improving teaching and learning. ${ }^{91}$ Testing and student achievement in the 90 s seems to be aware of the problem that multiple choice testing is not as effective and states have taken steps to find alternatives whether that means not using multiple choice for certain subjects or using a combination of multiple choice and these other methods. What are now a part of mandatory graduation requirements and subject testing: language arts, science, math, and social studies,

\footnotetext{
${ }^{88}$ Lawrence J. McAndrews, The Era of Education: The Presidents and the Schools, 1965-2001 (Champaign: University of Illinois Press, 2006), 137, ProQuest Ebook Central.

${ }^{89}$ McAndrews, The Era of Education: The Presidents and the Schools, 1965-2001, 13.

${ }^{90}$ Ibid, 149.

${ }^{91}$ Educational Resources Information Center, and Mid-Atlantic Lab. for Student Success, Philadelphia, PA, An Overview of Title I Schoolwide Programs Federal Legislative Expectations. Outlined in the Improving America's Schools Act of the 1994 Amendments to Title I of the Elementary and Secondary Education Act of 1965, by Kenneth K. Wong, Meye Comp., and Stephen Comp, Washington, D.C.: ERIC Clearinghouse, 1998, https://files.eric.ed.gov/fulltext/ED430073.pdf, Accessed November 22, 2020.
} 
states in the 90s were just beginning to include science and social studies into standardized tests. $^{92}$

Clinton reintroduced the question of the wealth gap. He supported more funding for education when he ran for president and as a result, the NEA endorsed him. They did not start out on the best of terms as Clinton originally wanted teacher testing, which the NEA disliked, so he dropped that as a part of his presidential campaign. ${ }^{93} \mathrm{He}$ wanted to transfer funds from the wealthier districts to the poorer districts, showing his effort of equity to lower income areas, drawing a correlation to Johnson's administration. The author McAndrews observed that he used a lot of the same rhetoric as Johnson and the Democrat party as a whole. Clinton signed the Improving America's Schools Act in 1994.

IASA supposed to do -

The instatement of the IASA, the revised ESEA, gave more power to states and districts by giving them autonomy to meet criteria by having an end goal. It was not made consistent so how states met these goals were up to the states. It held schools accountable for improving student achievement, and promoted partnerships between schools, families, and communities. Accountability of schools became focal at a state and local level to determine distribution of funding. Overall, in the IASA there are fifteen titles, in contrast to the ESEA, which consisted of seven total. This reflected a more encompassing policy that attended to new issues such as technology in education, as in Title 3. For the purposes of this thesis, the following titles are most significant in addressing these changes. Title 1 ensures accountability through standards and assessments developed by the state. Title 2 funds focus on teacher improvement efforts

\footnotetext{
${ }^{92}$ Ohio State Legislative Office of Education Oversight, Columbus, Measuring Student Achievement, n.a., Ohio: ERIC Clearinghouse, 1993, https://files.eric.ed.gov/fulltext/ED411290.pdf, Accessed March 7, 2021.

${ }^{93}$ Lawrence J. McAndrews, The Era of Education: The Presidents and the Schools, 1965-2001 (Champaign: University of Illinois Press, 2006), 122, ProQuest Ebook Central.
} 
based on plans created by districts or schools. It lets teachers and principals determine training. It may also be used for higher education programs or other professional institutions. ${ }^{94}$ Title 4 wants to meet goals of making schools violence and drug free with an evaluation to assess its impact. ${ }^{95}$ Title 5 was for funding towards schools promoting equity. This included efforts towards dropout prevention and secondary basic skills instruction. ${ }^{96}$ Title 15 provided general provisions. Of note is that this title provided funding for the National Center for Education Statistics. ${ }^{97}$ This demonstrates the effort of the IASA in expanding what gets funded and their collaboration to provide data.

The government wanted to make a point, pushing for family and community connections as a shared responsibility of a child's education. Programs were provided to include parents such as the Even Start Literacy Program. ${ }^{98}$ Attention was placed on equipment, resources and prevention programs to promote equity. Districts could use funds to coordinate services to address issues outside of school for students. ${ }^{99}$ Programs were established for children and youth who were neglected, delinquent, or at risk of dropping out, along with their intentions to lower dropout rates to below $10 \% .{ }^{100}$ The states had to comply with rules to apply for funds. They continued efforts of desegregation in schools. Education for homeless children and youth was

\footnotetext{
94 “Summary of the Improving America's Schools Act," Education Week, November 9, 1994, https:/www.edweek.org/education/summary-of-the-improving-americas-schools-act/1994/11.

${ }^{95}$ Department of Education, The Improving America's Schools Act of 1994. Reauthorization of the Elementary and Secondary Education Act, Washington D.C.: ERIC Clearinghouse, 1995, https://files.eric.ed.gov/fulltext/ED399649.pdf, Accessed January 19, 2021.

${ }^{96}$ Library of Congress, Washington, D.C. Congressional Research Service, Improving America's Schools Act: An Overview of P.L. 103-382. CRS Report for Congress, by James B. Stedman, CRS- 94-872-EPW, Washington D.C: ERIC Clearinghouse, October 1994, https:/files.eric.ed.gov/fulltext/ED379792.pdf, Accessed April 5, 2021.

97 "Summary of the Improving America’s Schools Act," Education Week, November 9, 1994, https://www.edweek.org/education/summary-of-the-improving-americas-schools-act/1994/11.

${ }^{98}$ Library of Congress, Washington, D.C. Congressional Research Service, Improving America's Schools Act: An Overview of P.L. 103-382. CRS Report for Congress.

${ }^{99}$ Department of Education, The Improving America's Schools Act of 1994. Reauthorization of the Elementary and Secondary Education Act, Washington D.C.: ERIC Clearinghouse, 1995, https://files.eric.ed.gov/fulltext/ED399649.pdf, Accessed January 19, 2021.

${ }^{100}$ Library of Congress, Washington, D.C. Congressional Research Service, Improving America's Schools Act: An Overview of P.L. 103-382. CRS Report for Congress, by James B. Stedman, CRS- 94-872-EPW, Washington D.C: ERIC Clearinghouse, October 1994, https://files.eric.ed.gov/fulltext/ED379792.pdf, Accessed April 5, 2021.
} 
included. Even though the act had high expectations, there was a lot of criticism at the time and skepticism in its ability to actually perform what it said it would do. ${ }^{101}$

\section{After IASA:}

Most sources evaluating the IASA were only done by individual states or districts. In this set up, the federal government's primary role was overseeing the funding of public schools and programs as well as providing resources to schools, but did not have further knowledge other than the data they were being given. The majority of the states had typical information of students such as graduation rates, teacher per students ratio, etc. Organizations began to focus on statistical data collection such as education statistics due to its increase of importance to policy. ${ }^{102}$ Many of the presidents thought that state and local districts should have more authority over education. States were becoming stricter with who could become a teacher as teacher training evolved. ${ }^{103}$ Curricula became more concrete by creating associations and organizations based on school subjects that review and construct standards for their specific subjects.

The IASA reauthorization ended in 1999. Questions arose about whether it was successfully implemented. Piche noted that,"Although states had six years to develop the six assessments called for under the 1994 law, by January 2001, only eleven states fully met Title 1 requirements for alignment with standards, technical quality, full inclusion of all students, and disaggregation of results by race, gender and other categories." ${ }^{104}$ Piche, in her assessment of the IASA, discussed a study done by the Office of Elementary and Secondary Education in 1999 that

\footnotetext{
${ }^{101}$ Library of Congress, Washington, D.C. Congressional Research Service, Improving America's Schools Act: An Overview of P.L. 103-382. CRS Report for Congress.

${ }^{102}$ Ibid, 10.

103 Lawrence J. McAndrews, The Era of Education: The Presidents and the Schools, 1965-2001 (Champaign: University of Illinois Press, 2006), 157, ProQuest Ebook Central.

${ }^{104}$ Citizens' Commission on Civil Rights, Closing the Deal: A Preliminary Report on State Compliance with Final Assessment \& Accountability Requirements under the Improving America's Schools Act of 1994, by Dianne M.

Piche, Washington D.C.: ERIC Clearinghouse, 2001, https://files.eric.ed.gov/fulltext/ED460200.pdf, Accessed April $18,2021$.
} 
looked at four states and noticed problems within their programs. Their conclusions were that states did not have the same criteria as to what they were analyzing. ${ }^{105}$ Not knowing what to do, “... the Clinton Administration decided not to review states' accountability systems, including their definitions of 'adequate yearly progress,' even though the same deadline (the 2000-01 school year) was set for compliance with these provisions." ${ }^{106}$ This meant the federal government was waiting to see which states gathered the information within the allotted time and it was all based on the pace of the states.

States decided upon when students should take assessments to measure if a student was learning what they needed to by a certain grade. The test would be taken three times: once in elementary school, once in junior high, and once in high school. ${ }^{107}$ A study defined an assessment as, "monitoring student growth, information and accountability for parents, student, and public, improving student performance, allocation of resources, selection and placement of students, certification of competence of students, program evaluation." ${ }^{108}$ Content standards would be measured and they would provide accommodation for students with diverse learning. ${ }^{109}$ They looked at assessment design from the national level to the classroom level in what was most effective with, "Large-scale assessment ... a key policy tool used to attempt to affect a change in the nation's schools." ${ }^{\prime 10}$ There was a debacle in figuring out what types of assessments

\footnotetext{
${ }^{105}$ Citizens' Commission on Civil Rights, Closing the Deal: A Preliminary Report on State Compliance with Final Assessment \& Accountability Requirements under the Improving America's Schools Act of 1994. 
should be used. The government questioned whether or not assessments should be developed from top-down or bottom up. They wanted to de-emphasize content matter and instead focus on application and use of content. ${ }^{111}$ Emerging techniques such as portfolios, projects, performance assessments, hands-on assessments, etc. were just starting to be used in classrooms. ${ }^{112}$ These new techniques however, were more feasible on a smaller scale like a classroom or school, but these did not seem to work well at a state or national level, where multiple choice and short answers were deemed more efficient. While portfolios can be seen as more applicable, it was qualitative information and not as easily measurable as a multiple choice where a student ends up with a numerical score. Such quantitative data was preferable by organizations.

\section{Conclusion:}

All decisions made in education were reactionary to what was going on internationally as a response. By the time the IASA was created, there were more people involved in the say of what education should be, essentially deteriorating the rate at which projects were actually able to get done. There were already many that were halted during the ESEA, but now with the IASA there were too many conflicting sides. The United States never was able to give full focus to its human capital because it was worried about protecting capitalism itself. By the U.S. acting as the "protectorate" of capitalism, we were neglecting our people at a time when they could have had opportunities. The position of attempting to fix education came at a time when the U.S. was

\footnotetext{
111 U.S. Department of Education, Educational Resources Information Center (ERIC), Designing Coordinated Assessment Systems for IASA Title I., by Edward D. Roeber, Illinois: ERIC Clearinghouse, 1997, ,https://files.eric.ed.gov/fulltext/ED410265.pdf, Accessed April 12, 2021.

${ }^{112}$ Citizens' Commission on Civil Rights, Closing the Deal: A Preliminary Report on State Compliance with Final Assessment \& Accountability Requirements under the Improving America's Schools Act of 1994, by Dianne M. Piche, Washington D.C.: ERIC Clearinghouse, 2001, https://files.eric.ed.gov/fulltext/ED460200.pdf, Accessed April 18, 2021.
} 
ready to focus and create change, but the government was either unwilling to or in some circumstances fell into a place where other matters required attention.

Many other leading countries in education today were not as involved in the Cold War, and saw themselves in competition with the U.S. For the majority of the 20 th century the U.S was focused on foreign policy and being the intervention against the Red Scare, these other countries focused inward to their human capital, prioritizing the people. All this extra money spent on war could have been used elsewhere, but because the president's priorities were always somewhere else, there was never a clear concentration. On top of that, there was a fight between the parties as well. There was a constant back and forth of money and how much was needed rather than how the money could be used. At the federal level, not much policy was getting through because of the polarity of politics where at the local levels more could get done because they were not worried about opposition. From the years of World War Two on, education was being used as a tool for militarization. This can be seen when during World War Two the government realized their soldiers were not as well educated leading to temporary legislation such as the GI Bill only to later be extended.

Reagan, even though a Republican, set up a future trajectory for Clinton being held accountable for the people involved in education had gone too long ignored. In doing so, it perfectly set up for Clinton to focus on education with few distractions. On top of that, Clinton had the advantage of being president when there was economic growth that was in a stable place. The ESEA determined who could get into what school but not what was learned, that did not start developing into "modern standards" until the 1994 reauthorization. Legislation has put more boxes around what could and could not be done in school. What was seeming to be the only helpful part were the programs that were created to address specific issues like Even Start. Since 
the 1960s, poverty has been increasing, and in that way, what the ESEA has set out to do has failed.

Since the creation of the ESEA, there are now more people in the playing field determining what goes on. At the federal level, not much was getting done because of the polarity of politics where at the local levels more could get done because they were not worried about opposition. However, the ESEA was dealing with years of inequities all at once, in a sense playing catch up to rectify racial injustice first within the country to expand upon in our schools. This alongside funding to schools was the reason why the ESEA holds such importance; the IASA developed and relied on student standards and helped to determine what students should be studying, which is still relevant today. With such encompassing pieces of legislation that directed funding, one would think that there would be measures to enforce such criteria to keep the guidelines effective. However, true to the original promise of Lyndon Johnson, there is very little federal control, especially within the IASA reauthorization, and much of that control belongs to the states. There is not much the Department of Education does to enforce its own guidelines or pull funds from schools. Additional research should be done on the reinforcement of these legislation in what keeps them effective.

Education policy is supposed to benefit students. They are the ones who all these players are supposed to be playing for. In this paper though, you will notice that there is no mention of the student. Throughout the twentieth century they did not have a voice. Only with some improvement is there any today. Politicians and organizations are pushing an agenda that is "for the students" or "the students" need more funding. Is it really? It is adults telling other adults what is best for their education when the trend has been that overall education policy is for the betterment of what an organization thinks and to address threats to national security. There may 
have been good intentions, but that was dismissed the moment these key figures in policy made it about their end goal rather than coming to a compromise instead being blindsided to just wanting to get their way leaving students hurt rather than helped. Federal funding did what it was supposed to do. It led to increased testing to measure student achievement. Student standards and student achievement were strictly tied to funding which is why the U.S. placed such a heavy focus on testing and grades. And yet, closing the wealth gap among students being a major aim of both the ESEA and the IASA, persists into the present day. They have put new barriers around these underprivileged students. The metrics by which the federal government measured success may not have provided instruments adequate to measure the effectiveness of these policies on students in their everyday lives. Really student achievement just puts quantitatively what was already known because it goes back to the issue of lack of wealth being a systemic one, one that cannot be as easily fixed by saying more funding is needed. 


\section{Bibliography}

“A Brief History of the Drug War,” Drug Policy Alliance, Drug Policy Alliance. 2020. https://drugpolicy.org/issues/brief-history-drug-war.

Ashby, Lyle W. "The National Education Association." The Phi Delta Kappan 31, no. 3 (1949): 99-121. Accessed December 3, 2020. http://www.jstor.org/stable/20331887.

Cardinal, Denise. "National Education Association." In Encyclopedia of Education, 2nd ed., edited by James W. Guthrie, 1769-1771. Vol. 5. New York, NY: Macmillan Reference USA, 2002. Gale eBooks. Accessed October 31, 2020.

https://link.gale.com/apps/doc/CX3403200451/GVRL?u=oregon_portland\&sid=GVRL\& $\underline{\text { xid }=9 \mathrm{e} 710060}$.

Casalaspi, David. "The Making of a "Legislative Miracle": The Elementary and Secondary Education Act of 1965." History of Education Quarterly 57, no. 2 (May, 2017): 247-277. doi:http://dx.doi.org/10.1017/heq.2017.4.

Congress of the U.S. Elementary and Secondary Education Act of 1965, Background Material With Related Presidential Recommendations. n.a. Washington D.C.: RIC Clearinghouse. 1965. https://files.eric.ed.gov/fulltext/ED018492.pdf, Accessed January 16, 2021.

Department of Education, The Improving America's Schools Act of 1994. Reauthorization of the Elementary and Secondary Education Act. n.a. Washington D.C.: ERIC Clearinghouse. 1995. https://files.eric.ed.gov/fulltext/ED399649.pdf, Accessed January 19, 2021.

Educational Resources Information Center, and Mid-Atlantic Lab. for Student Success, Philadelphia, PA. An Overview of Title I Schoolwide Programs Federal Legislative Expectations. Outlined in the Improving America's Schools Act of the 1994 Amendments to Title I of the Elementary and Secondary Education Act of 1965. Wong, Kenneth K., Comp., Meyer, Comp., Stephen. S.1.]: ERIC Clearinghouse. 1998. 1-17. https://files.eric.ed.gov/fulltext/ED430073.pdf. Accessed November 20, 2020.

Ferraro, Thomas. "Bush announces six "national education goals'.” UPI, United Press International, Inc. February 1, 1990. https://www.upi.com/Archives/1990/02/01/Bush-announces-six-national-education-goals/ 2945633848400/.

Germany, Kent. "Lyndon B. Johnson: Foreign Affairs.” UVA Miller Center, Rector and Visitors of the University of Virginia, 2021, https://millercenter.org/president/lbjohnson/foreign-affairs. 
Guthrie, James W. “A political case history: Passage of the ESEA.” Phi Delta Kappan, 49(6), (1968): 302-306. https://kappanonline.org/political-case-history-passage-esea-guthrie/.

Hana, Julia. "The Elementary and Secondary Education Act: 40 Years Later." Harvard Graduate School of Education. President and Fellows of Harvard College. last modified August 18, 2005 ,

https://www.gse.harvard.edu/news/05/08/elementary-and-secondary-education-act-40-ye ars-later.

Hoxby, Caroline Minter. "How teachers' unions affect education production." Quarterly Journal of Economics 111, no. 3 (1996): 671+. Gale OneFile: Business. Accessed November 7, 2020 , https://link.gale.com/apps/doc/A18673683/GPS? $\mathrm{u}=\mathrm{s} 1185784 \& \operatorname{sid}=\mathrm{GPS} \& \mathrm{xid}=3274 \mathrm{fc} 4 \mathrm{c}$.

Library of Congress, Washington, D.C. Congressional Research Service. Improving America's Schools Act: An Overview of P.L. 103-382. CRS Report for Congress. James B. Stedman. CRS- 94-872-EPW. Washington D.C: ERIC Clearinghouse. October 1994. https://files.eric.ed.gov/fulltext/ED379792.pdf, Accessed April 5, 2021.

McAndrews, Lawrence J. The Era of Education: The Presidents and the Schools, 1965-2001. Champaign: University of Illinois Press, 2006. Accessed November 1, 2020. ProQuest Ebook Central.

McElhoe, Janice Sweet. "Compensatory Education: A Comparison of the Design and Intent of Title I of the Elementary and Secondary Education Act: 1965 to 1994." diss., Pennsylvania State University, 1995. 22. http://stats.lib.pdx.edu/proxy.php?url=http://search.proquest.com.proxy.lib.pdx.edu/disser tations-theses/compensatory-education-comparison-design-intent/docview/304214718/se2? accountid=13265.

McGuinn, Patrick. "Schooling the State: ESEA and the Evolution of the U.S. Department of Education" RSF: The Russell Sage Foundation Journal of the Social Sciences 1, no. 3 (2015): 77-94. Accessed April 7, 2021, doi:10.7758/rsf.2015.1.3.04.

Mid-Continent Regional Educational Lab., Aurora, CO. National Educational Goals: Can They Lead Schools to Real Reform? Noteworthy Series. n.a. Washington D.C.: ERIC Clearinghouse. 1990. https://files.eric.ed.gov/fulltext/ED369139.pdf, Accessed February 9, 2021.

National Center on Education and the Economy, Rochester, NY. America's Choice: High Skills or Low Wages: The Report of the Commission on the Skills of the American Workforce. n.a. ISBN-0-9627063-0-2. New York: ERIC Clearinghouse. June 1990. https://files.eric.ed.gov/fulltext/ED323297.pdf, Accessed February 9, 2021. 
Office of Education DHEW, Washington, D.C. Div. of Compensatory Education, Staffing for Better Schools (Under Title I, Elementary and Secondary Education Act of 1965.) by Malcom Provus and Others, OE - 23049, Washington D.C.: ERIC Clearinghouse, 1967, https://files.eric.ed.gov/fulltext/ED034717.pdf, Accessed October 16, 2020.

Stephens, David. "President Carter, the Congress, and NEA: Creating the Department of Education." Political Science Quarterly 98, no. 4 (1983): 463. Accessed January 26, 2021, doi:10.2307/2149722.

"Summary of the Improving America's Schools Act." Education Week, November 9, 1994. https://www.edweek.org/education/summary-of-the-improving-americas-schools-act/199 $\underline{4 / 11}$.

The Pennsylvania State University. Janice Sweet McElhoe, "Compensatory Education: A Comparison of the Design and Intent of Title I of the Elementary and Secondary Education Act: 1965 to 1994" (PhD diss., The Pennsylvania State University, 1995), 22, http://stats.lib.pdx.edu/proxy.php?url=http://search.proquest.com.proxy.lib.pdx.edu/disser tations-theses/compensatory-education-comparison-design-intent/docview/304214718/se2? accountid $=13265$.

“Thirty Years of America's Drug War a Chronology," Frontline PBS, WGBH educational foundation. 2014. https://www.pbs.org/wgbh/pages/frontline/shows/drugs/cron/.

“Timeline: America's War on Drugs," NPR, NRP. April 2, 2007. https://www.npr.org/templates/story/story.php?storyId=9252490.

Truman Library. "Timeline of the Cold War." Accessed May 5, 2020, https://www.trumanlibrary.gov/public/TrumanCIA_Timeline.pdf.

Torstensson, David. "Beyond the City: Lyndon Johnson's War on Poverty in Rural America." Journal of Policy History 25, no. 4 (2013): 587-613. doi:10.1017/S0898030613000316.

United States. Department of Education, and Educational Resources Information Center. The Improving America's Schools Act of 1994. Reauthorization of the Elementary and Secondary Education Act. S.1.]: ERIC Clearinghouse. 1995. 1-14. https://files.eric.ed.gov/fulltext/ED399649.pdf. Accessed November 20, 2020.

U.S. Department of Education, National Center for Education Statistics. State Comparisons of Education Statistics: 1969-70 to 1996-97. Snyder T., Hoffman L., and Geddas C. 98-018. NCES: ERIC Clearinghouse. 1998. https://nces.ed.gov/pubs98/98018.pdf. Accessed November 6, 2020

U.S. Department of Health, Education \& Welfare, Office of Education, ELEMENTARY AND SECONDARY EDUCATION ACT OF 1965 Background Material With Related 
Presidential Recommendations. n.a. Office of Education: ERIC Clearinghouse. 1965. https://files.eric.ed.gov/fulltext/ED018492.pdf, Accessed February 12, 2021.

"What Is a PAC?," OpenSecrets.org, The Center for Responsive Politics. Accessed April 28, 2021, https://www.opensecrets.org/political-action-committees-pacs/what-is-a-pac.

Wood, Hugh B. Evaluation of Pupil Growth and Development; A Study-Guide for Students and Teachers. Urbana-Champaign: University of Illinois, 1940. HathiTrust. https://babel.hathitrust.org/cgi/pt?id=uiug.30112049873943\&view=1up\&seq=1.

Wu, Yi-Fang. The SAGE Encyclopedia of Educational Research, Measurement, and Evaluation. ed. Bruce B. Frey. Thousand Oaks: SAGE Publications, Inc., 2018. 28-33, http://dx.doi.org/10.4135/9781506326139. 